\title{
HUBUNGAN MOTIVASI DAN PENGGUNAAN APLIKASI PETANI SEBAGAI MEDIA PENYULUHAN DENGAN TINGKAT KEPUASAN PETANI
}

\section{The Relation Between Motivation and Uses of Petani Application as an Extension Media with Gratification Level of Farmer}

Nur Azizah Rizki Astuti ${ }^{1)}$ dan Hadiyanto ${ }^{1)}$

${ }^{1)}$ Departemen Sains Komunikasi dan Pengembangan Masyarakat, Fakultas Ekologi Manusia, Institut Pertanian Bogor, Darmaga Bogor 16680, Indonesia

Email: azizahrizki74@gmail.com; hadi62@apps.ipb.ac.id

\begin{abstract}
Petani application created as an alternative to support agricultural extension in Indonesia and encourage farmers to actively and independently contribute in their role as the subject of agricultural development. The objective of this research is to analyze what motivations that encourage farmers to use Petani application, how is farmer's frequency and intencity in using Petani apllication, and how is the relation between motivation and uses of Petani apllication with gratification level of farmer. This research using survey method to 30 respondents in Sleman Regency selected with simple random sampling. The result from this research shown that motivation, utilization, and gratification level of respondents in using Petani application correlate to each other. The motivation of using with frequency and intensity and user's gratification level has a positive and significant correlation while frequency and intensity of using with user's gratification level has a correlation but not too significant.
\end{abstract}

Keywords: gratification level, motivation, Petani application, uses.

\begin{abstract}
ABSTRAK
Aplikasi Petani hadir sebagai alternatif penunjang kegiatan penyuluhan pertanian di Indonesia dan mendorong petani untuk aktif dan berkontribusi secara mandiri dalam perannya sebagai subyek pembangunan pertanian. Penelitian ini bertujuan untuk menganalisis apa saja motivasi yang mendorong petani dalam menggunakan aplikasi Petani, bagaimana frekuensi dan intensitas penggunaan aplikasi Petani di kalangan petani pengguna, serta bagaimana hubungan motivasi dan penggunaan aplikasi Petani dengan tingkat kepuasan petani. Penelitian ini menggunakan metode survei kepada 30 petani responden di Kabupaten Sleman yang dipilih menggunakan teknik pengambilan sampel acak sederhana. Hasil penelitian menunjukkan bahwa motivasi, penggunaan, dan tingkat kepuasan responden dalam menggunakan aplikasi Petani berhubungan satu sama lain. Motivasi penggunaan dengan frekuensi dan intensitas serta tingkat kepuasan pengguna memiliki hubungan yang positif dan signifikan, sedangkan frekuensi dan intensitas penggunaan dengan tingkat kepuasan pengguna memiliki hubungan tetapi tidak terlalu signifikan.
\end{abstract}

Kata kunci: aplikasi Petani, motivasi, penggunaan, tingkat kepuasan.

\section{PENDAHULUAN}

Indonesia saat ini menghadapi kekurangan jumlah penyuluh pertanian. Jumlah penyuluh pertanian yang bertugas di masing-masing desa atau kelurahan saat ini sebanyak 12.007 PNS untuk melayani 71.479 desa atau kelurahan potensi pertanian (BPPSDMP 2016). Menurut Undang-Undang Nomor 19 Tahun 2013 tentang Perlindungan dan Pemberdayaan Petani serta Peraturan Menteri Pertanian Nomor 72 Tahun
2011 tentang Pedoman Penyusunan Formasi Jabatan Fungsional Penyuluh Pertanian, disebutkan bahwa paling sedikit ada satu orang penyuluh dalam satu desa potensi pertanian. Dengan jumlah tersebut, saat ini Indonesia masih membutuhkan sebanyak 59.472 orang penyuluh untuk memenuhi kekurangan yang ada.

Kegiatan penyuluhan tidak hanya dapat dilakukan melalui pertemuan tatap muka. Untuk mengatasi permasalahan kekurangan tenaga 
penyuluh pertanian di desa-desa di Indonesia, saat ini telah banyak dikembangkan metode penyuluhan berbasis teknologi informasi dan komunikasi (TIK). Pengembangan metode penyuluhan berbasis TIK ini didukung dengan semakin terdedahnya masyarakat di pedesaan terhadap akses internet. Metode penyuluhan berbasis TIK ini lebih mengedepankan pola komunikasi yang dialogis dan partisipatif dari petani.

Jumlah penyuluh pertanian yang relatif sedikit dan kurang menunjang sistem penyuluhan Laku (Latihan dan Kunjungan) serta adanya fakta bahwa lebih dari 70 persen petani memiliki handphone (HP) dan 12 persennya menggunakan internet melalui $\mathrm{HP}^{1}$, kemudian mendorong terbentuknya Layanan Informasi Desa (LISA) yang kemudian berkembang menjadi aplikasi Petani. Kepemilikan HP dan penggunaan internet oleh petani kemudian menjadi tantangan bagaimana mengarahkan petani menggunakan HP untuk tujuan produktif, bukan konsumtif.

Berdasarkan hasil penelitian Kuntoro (2016), petani di Karawang sudah mulai menggunakan handphone untuk mengakses informasi pertanian melalui Layanan Informasi Desa (LISA). Petani dapat menggunakan HP untuk mendapatkan informasi seputar pertanian mulai dari perencanaan usahatani sampai pada tahap pemasaran hasil pertanian. LISA menjadi pilihan utama petani untuk dijadikan sumber informasi dibanding sumber informasi dari media elektronik lainnya. Hal tersebut dikarenakan mudahnya prosedur dalam mengakses informasi melalui LISA dan tidak dikenakan biaya akses sedikitpun.

Aplikasi Petani hadir sebagai alternatif penunjang kegiatan penyuluhan pertanian di Indonesia. Aplikasi Petani memungkinkan komunikasi dua arah antara satu petani dengan petani lain, atau petani dengan penyuluh, akademisi, dan mitra bisnisnya. Aplikasi ini mendorong petani untuk aktif dan berkontribusi secara mandiri dalam perannya sebagai subyek

\footnotetext{
${ }^{1}$ Dikutip dari presentasi Agri-Fin Mobile oleh Andi Ikhwan pada 16 September 2014 yang disampaikan pada Seminar Departemen Sains Komunikasi dan Pengembangan Masyarakat, Fakultas Ekologi Manusia, IPB
}

pembangunan pertanian. Dalam menggunakan suatu media, dalam hal ini aplikasi, terdapat suatu dorongan atau motivasi yang membuat seseorang, dalam hal ini petani, menggunakan aplikasi tersebut. Motivasi yang dimaksud tentu berkaitan dan memengaruhi pola penggunaan aplikasi oleh petani. Untuk itu, penting untuk melihat bagaimana hubungan motivasi dan penggunaan aplikasi Petani sebagai media penyuluhan dengan tingkat kepuasan petani?

Seseorang memiliki motif tersendiri dalam mengakses dan menggunakan suatu media. Motif sebagai sesuatu yang ada pada diri individu yang menggerakkan atau membangkitkan sehingga individu tersebut dapat melakukan sesuatu. Motivasi setiap individu dalam menggunakan media ini berbeda tergantung pada motif yang ada dalam dirinya. Sejumlah harapan dianggap akan dapat dipenuhi dengan cara mengonsumsi media. Untuk itu, penting untuk melihat apa saja motivasi yang mendorong petani menggunakan aplikasi Petani?

Berbagai informasi dapat diperoleh melalui media massa, baik yang bersifat umum ataupun khusus, penyajiannya yang didukung visualisasi yang menarik, sehingga media massa merupakan salah satu saluran komunikasi massa yang efektif dalam penyampaian informasi pertanian. Hal ini dikarenakan media massa relatif mampu menembus ruang dan waktu, menjangkau khalayak yang banyak dalam satuan waktu yang relatif singkat. Penggunaan media berkaitan dengan jumlah waktu yang digunakan dalam berbagai jenis isi media yang dikonsumsi. Untuk itu, penting untuk melihat bagaimana frekuensi dan intensitas penggunaan aplikasi Petani yang dilakukan petani?

\section{PENDEKATAN TEORITIS}

\section{Penggunaan TIK dalam Penyuluhan}

Perkembangan teknologi informasi dan komunikasi (TIK) telah memberikan kontribusi yang nyata dalam proses berkembangnya sistem pengembangan informasi pertanian, khususnya sebagai media komunikasi inovasi pertanian. Integrasi yang efektif antara TIK dalam sektor pertanian menuju pada pertanian berkelanjutan melalui penyiapan informasi pertanian yang 
tepat waktu yang relevan dapat memberikan informasi yang tepat kepada petani dalam proses pengambilan keputusan berusahatani untuk meningkatkan produktivitasnya (Sumardjo et al. 2011). TIK dapat meningkatkan aksesibilitas petani terhadap informasi pasar, input produksi, tren konsumen, yang secara positif berdampak pada kualitas dan kuantitas produksi mereka.

TIK dapat memberikan informasi kepada para petani dalam bentuk pemeliharaan tanaman dan hewan, pemberian pupuk dan pakan hewan, pengurangan dampak kemarau, pemberantasan hama, irigasi, ramalan cuaca, sumber benih, dan harga pasaran. Kegunaan TIK juga menguntungkan para petani dalam hal memungkinkan mereka ikut serta dalam kegiatan advokasi dan kooperasi.

Salah satu penerapan TIK untuk menunjang komunikasi inovasi pertanian adalah cyber extension. Cyber extension adalah mekanisme pertukaran informasi pertanian melalui area cyber, suatu ruang imajiner maya di balik interkoneksi jaringan computer melalui peralatan komunikasi (Mulyandari et al. 2010). Sebuah cyber extension memberikan dukungan pada keseluruhan proses produksi, manajemen, pemasaran, dan kegiatan pembangunan pedesaan lainnya. Strategi implementasi cyber extension berpusat pada optimalisasi fungsi Badan Penyuluhan Kabupaten sebagai pusat akses informasi berbasis aplikasi teknologi informasi. Badan Penyuluhan Kabupaten menjembatani antara sumber informasi di pusat dengan stakeholders lokal sekaligus sebagai pemadu sistem. Badan Penyuluhan Kabupaten juga dapat berfungsi sebagai penghimpun informasi dari sumber informasi lokal melalui Badan Penyuluhan tingkat Kecamatan yang menghimpun informasi sekaligus memfasilitasi materi informasi bagi penyuluh lapangan yang berada di tiap desa.

Sebagai salah satu ujung tombak keberhasilan pangan Indonesia, profesi petani juga membutuhkan kegiatan berbagi informasi dan berita terbaru mengenai media komunikasi yang praktis untuk digunakan. Salah satu startup teknologi bernama 8villages meluncurkan suatu aplikasi android baru bernama Petani. 8villages hadir untuk memfasilitasi dan menjawab permasalahan para petani yang biasanya mengalami keterbatasan dalam memperoleh informasi dan pengetahuan terkini seputar pertanian. Kehadiran aplikasi Petani bertujuan untuk mewadahi komunitas petani dan mengedukasi para petani Indonesia dengan informasi seputar pertanian (Maxmanroe 2016)

Aplikasi Petani juga bertujuan untuk memudahkan pertukaran informasi antara pakar pertanian dan petani ketika petani mengalami kesulitan dalam budidaya tanaman (Agronomers 2016). Melalui aplikasi ini, petani bisa mengirimkan foto kondisi tanaman dan detailnya ke aplikasi, kemudian pakar akan menjawab permasalahan tersebut. Aplikasi ini juga seperti forum online untuk komunikasi antara petani lainnya dalam berbagi pengalaman dan informasi. Selain itu, aplikasi ini dapat digunakan pengguna untuk memberikan informasi hasil panen beserta harga dan menjual ke pembeli tanpa perantara.

\section{Motivasi Penggunaan Media}

Motivasi setiap individu dalam menggunakan media ini berbeda tergantung pada motif yang ada dalam dirinya. McQuail (1987) menyatakan bahwa kebutuhan, motif, penggunaan media, dan fungsi media saling berhubungan sedemikian rupa sehingga kebutuhan manusia tersebut menciptakan upaya pemenuhan kebutuhan. Sejumlah harapan dianggap akan dapat dipenuhi dengan cara mengonsumsi media massa atau dengan sejumlah alternatif fungsional lainnya. Khalayak dengan sengaja menggunakan media, maka hal ini disebut self-exposure. Motivasi penggunaan media atau fungsi media bagi individu meliputi motivasi informasi, motivasi identitas pribadi, motivasi integrasi dan interaksi sosial, serta motivasi hiburan. Merton dalam McQuail (1987) menyatakan bahwa seseorang menggunakan media massa apabila hal tersebut dianggap memberikan kepuasan pada kebutuhannya.

\section{Penggunana Media}

Berbagai informasi dapat diperoleh melalui media massa, baik yang bersifat umum ataupun khusus, penyajiannya yang didukung visualisasi yang menarik, sehingga media massa merupakan salah satu saluran komunikasi massa yang 
efektif dalam penyampaian informasi pertanian, hal ini dikarenakan media massa relatif mampu menembus ruang dan waktu menjangkau khalayak yang banyak dalam satuan waktu yang relatif singkat. Penggunaan dan pemanfaatan media komunikasi berperan penting guna menunjang kegiatan pertanian.

Penggunaan media dapat dikaji melalui teori uses and gratifications milik Blumer dan Katz yang menyatakan bahwa pengguna media memainkan peran aktif untuk memilih dan menggunakan media tersebut, atau dengan kata lain pengguna media adalah pihak yang aktif dalam proses komunikasi. Pengguna media berusaha untuk mencari sumber media yang paling baik di dalam usaha memenuhi kebutuhannya. Artinya, teori ini mengasumsikan bahwa pengguna mempunyai pilihan alternatif untuk memuaskan kebutuhannya (Nurudin 2007).

Teori uses and gratifications lebih menekankan pada pendekatan manusiawi dalam melihat media massa. Konsumen media mempunyai kebebasan untuk memutuskan bagaimana (lewat media mana) mereka menggunakan media dan bagaimana media itu akan berdampak pada dirinya. Teori uses and gratifications menjelaskan mengenai kapan dan bagaimana audiens sebagai konsumen media menjadi lebih aktif atau kurang aktif dalam menggunakan media dan akibat atau konsekuensi dari penggunaan media itu (Morissan et al. 2010).

Penggunaan media terdiri atas jumlah waktu yang digunakan dalam berbagai jenis isi media yang dikonsumsi dan berbagai hubungan antara individu konsumen media dengan isi media yang dikonsumsi atau dengan media secara keseluruhan.

\section{Kepuasan Terhadap Layanan Media}

Kepuasan adalah hasil dari penilaian khalayak bahwa media massa telah memberikan apa yang menjadi kebutuhan khalayak. Kita bisa memahami interaksi orang dengan media melalui pemanfaatan media oleh orang tersebut (uses) dan tingkat kepuasan yang diperoleh (gratifications). Gratifikasi yang sifatnya umum antara lain pelarian dari rasa khawatir, peredaan rasa kesepian, dukungan emosional, peroleh informasi, dan kontak sosial (Nurudin 2004). Kepuasan khalayak berkaitan dengan perasaan. Apabila perasaan yang dirasakannya telah sesuai dengan harapan, serta dapat memenuhi kebutuhannya, maka kepuasan khalayak tersebut telah terpenuhi.

Terdapat dua konsep kepuasan dalam teori uses and gratifications, yang meliputi:

(1) Gratifications sought (GS): sebagai keyakinan seseorang terhadap apa yang media dapat berikan dan penilaian seseorang terhadap isi suatu media

(2) Gratifications obtained (GO): kepuasan yang didapat oleh seseorang setelah menggunakan atau mengonsumsi media

\section{Kerangka Pemikiran}

Seseorang memiliki motif tersendiri dalam mengakses media. Motif seseorang dalam menggunakan media massa dapat dikategorikan sebagai usaha pencarian informasi, yang mana berkaitan dengan mencari bimbingan menyangkut masalah praktis, pendapat, dan halhal yang berkaitan dengan penentuan pilihan, memuaskan rasa ingin tahu, dan juga belajar. Motif penggunaan media massa dapat juga untuk tujuan integrasi dan interaksi sosial yang memungkinkan seseorang untuk memperoleh pengetahuan tentang orang lain, empati sosial, mengidentifikasi diri dengan orang lain dan meningkatkan rasa memiliki, serta membantu menjalankan peran sosial.

Penggunaan media terdiri atas jumlah waktu yang digunakan dalam berbagai jenis isi media yang dikonsumsi. Motivasi dan penggunaan media kemudian menghasilkan kepuasan pengguna dalam menggunakan suatu media. Kepuasan pengguna ini berkaitan dengan apa yang didapat oleh seseorang setelah menggunakan suatu media.

Motivasi dalam menggunakan media diduga berhubungan dengan frekuensi dan intensitas penggunaan media itu. Frekuensi dan intensitas penggunaan media tentu berbeda setiap individu tergantung dari motivasi apa yang mendasarinya menggunakan media tersebut. Lebih lanjut, penggunaan media yang didasari oleh motivasi menggunakan media tersebut diduga berkaitan 
dengan tingkat kepuasan yang dirasakan pengguna yang sesuai dengan motivasi apa yang mendasarinya menggunakan media tersebut.

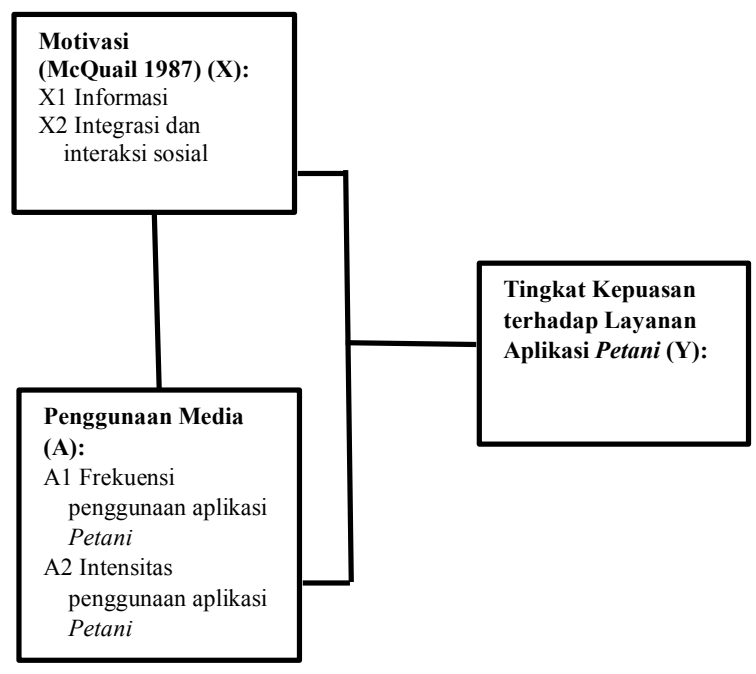

Keterangan: berhubungan

\section{Hipotesis}

Penelitian ini memiliki delapan hipotesis yaitu:

1. Diduga terdapat hubungan nyata antara motivasi informasi dalam menggunakan aplikasi dengan frekuensi penggunaan aplikasi Petani

2. Diduga terdapat hubungan nyata antara motivasi informasi dalam menggunakan aplikasi dengan intensitas penggunaan aplikasi Petani

3. Diduga terdapat hubungan nyata antara motivasi informasi dalam menggunakan aplikasi dengan tingkat kepuasan pengguna aplikasi Petani

4. Diduga terdapat hubungan nyata antara motivasi integrasi dan interaksi sosial dalam menggunakan aplikasi dengan frekuensi penggunaan aplikasi Petani

5. Diduga terdapat hubungan nyata antara motivasi integrasi dan interaksi sosial dalam menggunakan aplikasi dengan intensitas penggunaan aplikasi Petani

6. Diduga terdapat hubungan nyata antara motivasi integrasi dan interaksi sosial dalam menggunakan aplikasi dengan tingkat kepuasan pengguna aplikasi Petani

7. Diduga terdapat hubungan nyata antara frekuensi penggunaan aplikasi Petani dengan tingkat kepuasan pengguna

8. Diduga terdapat hubungan nyata antara intensitas penggunaan aplikasi Petani dengan tingkat kepuasan pengguna

\section{PENDEKATAN LAPANG}

Penelitian ini menggunakan pendekatan kuantitatif yang didukung dengan data kualitatif. Pendekatan kuantitatif digunakan untuk menjawab pertanyaan mengenai motivasi dalam menggunakan aplikasi Petani, penggunaan media yang berkaitan dengan jumlah waktu yang digunakan dalam berbagai jenis isi media, serta tingkat kepuasan yang diperoleh petani setelah menggunakan aplikasi Petani. Data kuantitatif diperoleh dengan menggunakan instrumen kuesioner. Data kualitatif digunakan untuk memperkuat data kuantitatif. Pengambilan data kualitatif dilakukan dengan wawancara mendalam (indepth interview) menggunakan panduan pertanyaan kepada para informan.

Penelitian ini ditujukan kepada petani pengguna aplikasi Petani di wilayah Kabupaten Sleman, Daerah Istimewa Yogyakarta. Pemilihan lokasi penelitian ini dilakukan secara sengaja (purposive) dengan pertimbangan Kabupaten Sleman merupakan lokasi peluncuran aplikasi Petani untuk pertama kalinya dan Kabupaten Sleman merupakan lokasi di mana terdapat paling banyak pengguna aktif aplikasi Petani, baik dari petani, pegiat agribisnis, maupun akademisi yang berfokus di dunia pertanian. Penelitian ini dilaksanakan pada bulan April 2017.

\section{Teknik Penentuan Responden dan Informan}

Pemilihan responden pada penelitian ini dilakukan menggunakan pengambilan sampel acak sederhana (simple random sampling) dengan populasi pengguna aplikasi Petani di Kabupaten Sleman adalah sebanyak 77 orang. Responden pada penelitian ini diambil sebanyak 30 orang. Responden adalah pengguna aplikasi Petani dan telah merasakan manfaat dari penggunaan aplikasi tersebut terhadap usaha 
atau kegiatan pertaniannya. Informan dalam penelitian ini meliputi pihak pengelola aplikasi Petani, yaitu PT 8villages Indonesia serta Kepala Bidang Penyuluhan di Dinas Pertanian, Perikanan, dan Peternakan Kabupaten Sleman.

\section{Teknik Pengumpulan Data}

Data yang dibutuhkan dalam penelitian ini meliputi data primer dan data sekunder. Data primer diperoleh secara langsung di lokasi penelitian dengan menggunakan instrumen kuesioner kepada responden, panduan pertanyaan untuk wawancara mendalam kepada responden dan informan, serta observasi mengenai kondisi petani di lapang yang berhubungan dengan penggunaan aplikasi Petani. Data sekunder berupa data dari Badan Pusat Statistik (BPS), data potensi wilayah, jumlah sebaran pengguna aplikasi Petani, serta data-data terkait yang berasal dari penelitian sebelumnya dalam bentuk jurnal ilmiah maupun skripsi.

\section{Teknik Pengolahan dan Analisis Data}

Data pada penelitian ini diolah menggunakan aplikasi Microsoft Excel 2016 dan IBM SPSS Statistics 24.0. Aplikasi Microsoft Excel 2016 digunakan untuk membuat tabel frekuensi, grafik, atau diagram untuk melihat data awal responden untuk masing-masing variabel secara tunggal. Kemudian IBM SPSS Statistics 24.0 digunakan untuk uji statistik yang menggunakan Rank Spearman Correlation untuk menguji ada atau tidaknya hubungan antara dua variabel yang berskala ordinal. Data kualitatif dianalisis melalui tiga tahap, yaitu reduksi data, penyajian data, dan verifikasi data.

\section{HASIL DAN PEMBAHASAN}

\section{Aplikasi Petani}

Aplikasi Petani diluncurkan oleh perusahaan berbasis Information Technology (IT) yang bernama PT. 8 villages Indonesia. Ide awal pembuatan aplikasi Petani adalah adanya fakta lapangan bahwa jumlah penyuluh pertanian relatif sedikit dan kurang menunjang sistem penyuluhan Laku (Latihan dan Kunjungan). Selain itu, jumlah rumah tangga tani pemilik handphone (HP) terbilang cukup tinggi, yaitu lebih dari 70 persen petani memiliki HP dan 12 persennya menggunakan internet melalui HP. Hal ini menjadi tantangan bagaimana mengarahkan petani menggunakan HP untuk tujuan produktif, bukan konsumtif.

Pada tahun 2012 diluncurkanlah Layanan Informasi Desa (LISA) yang berupa edukasi kepada petani melalui SMS. Edukasi LISA melalui SMS inilah yang menjadi cikal bakal aplikasi Petani berbasis Android yang ada sekarang. Aplikasi Petani berbasis Android mulai dikembangkan pada tahun 2014 dan terintergrasi dengan WEB dan juga SMS. Aplikasi Petani berbasis Android melayani tanya jawab, survei, profiling petani, dan menyediakan artikel-artikel yang terkait dengan kegiatan pertanian. Pada tahun 2016, mulai ditambahkan fitur Toko pada aplikasi Petani dan lapor panen berbasis digital.

Aplikasi Petani memiliki sepuluh fitur atau layanan yang dapat dimanfaatkan petani sesuai dengan kebutuhannya. Layanan yang ada pada aplikasi Petani meliputi layanan Tanya Jawab, Artikel, Video, Toko, Panen, Survey, Informasi SMS, Informasi Cuaca, Informasi Harga, dan Informasi Pupuk.

Aplikasi Petani dapat diunduh melalui layanan Google PlayStore secara gratis. Pengguna juga tidak dikenakan biaya apapun untuk menikmati layanan dari aplikasi Petani.

\section{Karakteristik Responden}

Usia pengguna aplikasi Petani sangat bervariasi. 40 persen pengguna berusia $30-40$ tahun. Sebaran usia pengguna didominasi oleh pengguna pada usia produktif dan mereka yang sudah terdedah teknologi. Responden pengguna aplikasi Petani 90 persennya adalah laki-laki dan 10 persen sisanya adalah pengguna perempuan. Pendidikan terakhir pengguna aplikasi Petani didominasi lulusan SMA, yaitu sebesar 56,7 persen.

Mayoritas responden, yaitu sebesar 66,7 persen sudah menjadi pengguna aplikasi Petani selama $1-6$ bulan. Mereka mendapatkan informasi adanya aplikasi Petani dari berbagai sumber, yaitu dari teman sesama pengguna, Google PlayStore, berita peluncuran aplikasi Petani di televisi, media sosial, dan workshop pertanian. 


\section{Motivasi Informasi}

Motivasi untuk mendapatkan informasi dapat dipenuhi melalui semua layanan dalam aplikasi Petani. Pengguna dapat bertanya mengenai masalah pertanian yang dialaminya, memuaskan rasa ingin tahu, belajar hal-hal baru secara mandiri, dan menambah pengetahuan melalui layanan dan konten-konten yang ada dalam aplikasi Petani.

Motivasi pengguna untuk mendapatkan informasi dari aplikasi Petani berada pada kategori sedang dan tinggi yang masing-masing memiliki persentase 50 persen. Hal ini menunjukkan bahwa pengguna aplikasi Petani telah secara aktif dan mandiri menggunakan aplikasi Petani sebagai sarana untuk mencari informasi serta bertanya hal-hal yang menyangkut usaha pertaniannya. Petani juga menggunakan aplikasi ini untuk menambah pengetahuan seputar dunia pertanian, atau menjadikannya referensi untuk membuka usaha pertanian baru.

Layanan aplikasi Petani yang paling banyak diakses oleh pengguna adalah layanan Tanya Jawab dan Artikel. Kedua layanan ini menyediakan informasi seputar pertanian yang dapat dengan mudah diakses oleh petani. Informasi yang ada pada layanan Artikel diperbarui secara berkala oleh admin dari PT 8villages Indonesia, sehingga informasi yang tersedia menjadi beragam dan pengguna dapat memilih informasi apa yang ingin mereka ketahui. Khusus pada layanan Tanya Jawab, selain mendapatkan informasi dari jawaban para pakar, pengguna juga dapat belajar dari pengalaman pengguna lain yang bertanya di kolom tanya jawab.

\section{Motivasi Integrasi dan Interaksi Sosial}

Aplikasi Petani memungkinkan penggunanya untuk berinteraksi satu sama lain dan mengetahui keadaan pengguna lain, serta mengidentifikasi diri dengan orang lain melalui beberapa layanannya. Layanan dalam aplikasi Petani yang dapat digunakan untuk memenuhi motivasi integrasi dan interaksi sosial meliputi layanan Tanya Jawab, Panen, dan Toko. Ketiga layanan tersebut memungkinkan pengguna aplikasi Petani untuk saling berinteraksi.

Motivasi interaksi dan integrasi sosial dalam menggunakan aplikasi Petani mayoritas berada dalam kategori sedang, yaitu sebesar 70 persen, dan sisanya berada dalam kategori tinggi, yaitu sebesar 30 persen. Hal ini disebabkan pengguna aplikasi Petani yang mengakses menu Panen dan Toko hanyalah mereka yang memiliki usaha agribisnis dan memang berniat memasarkan usahanya melalui aplikasi ini, sehingga motivasi mereka untuk berinteraksi dengan pengguna lain melalui aplikasi Petani tergolong lebih rendah jika dibandingkan dengan motivasi mereka untuk mendapatkan informasi.

\section{Frekuensi Penggunaan Aplikasi Petani}

Frekuensi penggunaan media pada penelitian ini merujuk pada berapa kali dalam satu bulan seorang pengguna menggunakan aplikasi Petani. Akses pada aplikasi Petani menunjukkan seberapa aktif pengguna menggunakan aplikasi ini dan seberapa besar manfaat yang telah didapatkan oleh pengguna.

Frekuensi penggunaan aplikasi Petani 83,3 persen berada pada kategori rendah. Hal ini disebabkan karena tidak seperti pada penggunaan media sosial lain, pengguna aplikasi Petani tidak mengakses aplikasi ini setiap hari. Pengguna hanya mengakses aplikasi Petani pada saat mereka membutuhkan suatu informasi tertentu atau ingin mendapatkan jawaban dari masalah pertanian mereka.

Layanan aplikasi Petani yang paling banyak diakses oleh pengguna dari segi frekuensi adalah layanan Tanya Jawab, Artikel, dan Informasi Harga. Rata-rata frekuensi penggunaan untuk layanan Tanya Jawab adalah empat kali dalam satu bulan, untuk layanan artikel adalah lima kali dalam satu bulan, dan untuk layanan Informasi Harga adalah tiga kali dalam satu bulan.

\section{Intensitas Penggunaan Aplikasi Petani}

Intensitas penggunaan media pada penelitian ini merujuk pada berapa lama waktu yang dialokasikan pengguna dalam satu kali mengakses aplikasi Petani. Seperti halnya pada frekuensi, intensitas penggunaan juga mengindikasikan seberapa aktif pengguna dalam 
menggunakan aplikasi Petani dan seberapa besar manfaat yang sudah mereka peroleh.

Intensitas penggunaan aplikasi Petani 86,7 persen berada pada kategori rendah. Hal ini menunjukkan bahwa pengguna tidak banyak mengalokasikan waktunya untuk menggunakan aplikasi Petani. Pengguna hanya mengakses aplikasi ini saat membutuhkan informasi atau ingin bertanya mengenai masalah pertaniannya. Jika kebutuhan akan informasi dan jawaban pertanyaan telah terpenuhi, mereka akan menyudahi aktivitas mereka dalam menggunakan aplikasi Petani.

Seperti halnya pada frekuensi akses layanan tertinggi, pengguna juga mengalokasikan waktunya lebih banyak untuk mengakses layanan Tanya Jawab, Artikel, dan Informasi Harga. Rata-rata intensitas untuk penggunaan layanan Tanya Jawab dalam satu hari adalah 12 menit, untuk layanan Artikel adalah 11 menit, dan untuk layanan Informasi Harga adalah delapan menit. Ketiga layanan tersebut beserta semua jenis informasi yang terdapat di dalamnya membuat pengguna lebih tertarik dan memilih untuk lebih lama mengalokasikan waktunya untuk mengakses layanan tersebut. Pengguna dapat memilih informasi apa yang mereka ingin dapatkan dan akan bermanfaat untuk mereka.

\section{Tingkat Kepuasan Pengguna Aplikasi Petani}

Kepuasan terhadap layanan aplikasi Petani merujuk pada kepuasan yang diperoleh responden setelah menggunakan aplikasi Petani yang berkaitan dengan kebutuhannya untuk memperoleh informasi serta untuk berinteraksi dan berbagi pengalaman dengan pengguna lain.

Kepuasan pengguna paling banyak berkaitan dengan terpenuhinya kebutuhan akan informasi pertanian melalui konten-konten yang ada di aplikasi Petani. Kepuasan pengguna juga didapat melalui terpenuhinya kebutuhan akan informasi mengenai harga pertanian di pasar, dapat belajar dari pengalaman pengguna lain, dapat bertanya mengenai masalah pertaniannya, serta mengetahui keadaan pengguna lain yang memiliki masalah pertanian yang sama.

Sebanyak 63,3 persen tingkat kepuasan pengguna terhadap layanan aplikasi Petani berada pada kategori sedang. Hal ini menunjukkan kepuasan pengguna terhadap layanan di aplikasi Petani yang berkaitan dengan kebutuhan mereka akan informasi serta untuk berinteraksi dan berbagi pengalaman dengan pengguna lain. Pengguna dapat mencari informasi yang sesuai dengan kebutuhannya, belajar dari pengalaman orang lain, maupun informasi lain yang penting dan erat hubungannya dengan usaha pertanian mereka.

\section{Hubungan Motivasi Informasi dengan Frekuensi Penggunaan Aplikasi Petani}

Motivasi seseorang dalam mengakses media bisa saja berbeda satu sama lain. Motivasi yang berbeda inilah yang memungkinkan tingkat penggunaan media masing-masing pengguna juga berbeda. Motivasi yang mendorong seseorang menggunakan media akan berpengaruh terhadap seberapa sering dan seberapa banyak waktu yang dialokasikan orang tersebut untuk mengakses media dalam rangka memenuhi motivasinya tersebut.

Mayoritas pengguna dengan tingkat motivasi sedang memiliki frekuensi penggunaan aplikasi Petani pada tingkat rendah, yaitu sebesar 93,3 persen, dan sisanya berada pada kategori frekuensi penggunaan sedang, yaitu sebesar 6,7 persen. Pengguna dengan tingkat motivasi tinggi memiliki frekuensi penggunaan yang lebih beragam, yaitu rendah sebesar 73,3 persen, sedang sebesar 20 persen, dan tinggi sebesar 6,7 persen. Hal ini menunjukkan bahwa motivasi untuk memperoleh informasi memiliki hubungan dengan frekuensi penggunaan aplikasi Petani. Keduanya berkorelasi dengan $p$ value 0.009 dan koefisien korelasi sebesar 0.470 , yang artinya keduanya memiliki hubungan yang positif dan sangat signifikan.

\section{Hubungan Motivasi Informasi dengan Frekuensi Penggunaan Aplikasi Petani}

Motivasi yang mendorong seseorang untuk mengakses media juga berhubungan dengan berapa lama waktu yang dialokasikannya untuk mengakses suatu media. Artinya, motivasi yang mendorong pengguna untuk mengakses media akan berhubungan dengan intensitas pengguna dalam mengunakan suatu media. 
Mayoritas pengguna dengan tingkat motivasi sedang memiliki intensitas penggunaan aplikasi Petani pada tingkat rendah, yaitu sebesar 93,3 persen, dan sisanya berada pada kategori intensitas penggunaan sedang, yaitu sebesar 6,7 persen. Pengguna dengan tingkat motivasi tinggi memiliki intensitas penggunaan yang lebih beragam, yaitu rendah sebesar 80 persen, sedang sebesar 13.3 persen, dan tinggi sebesar 6.7 persen. Hal ini menunjukkan bahwa motivasi untuk memperoleh informasi memiliki hubungan dengan intensitas penggunaan aplikasi Petani. Keduanya berkorelasi dengan $\mathrm{p}$ value 0.014 dan koefisien korelasi sebesar 0.444 , yang artinya keduanya memiliki hubungan yang positif dan signifikan.

\section{Hubungan Motivasi Informasi dengan Tingkat Kepuasan Pengguna Aplikasi Petani}

Motivasi yang berbeda yang mendorong setiap orang dalam menggunakan media akan memberikan pengalaman yang berbeda pula kepada orang tersebut selama mengakses suatu media. Pengalaman yang berbeda inilah yang menghasilkan tingkat kepuasan yang berbeda pula untuk setiap individu yang mengakses media. Kepuasan akan diperoleh individu jika motivasinya dalam mengakses media telah terpenuhi.

Mayoritas pengguna dengan tingkat motivasi sedang memiliki tingkat kepuasan sedang, yaitu sebesar 86,7 persen, dan sisanya berada pada tingkat kepuasan tinggi, yaitu sebesar 13,3 persen. Selebihnya pada motivasi informasi yang tinggi, mayoritas pengguna berada pada tingkat kepuasan tinggi, yaitu sebesar 60 persen, dan sisanya berada pada tingkat kepuasan sedang, yaitu sebesar 40 persen. Hal ini menunjukkan bahwa motivasi informasi memiliki hubungan dengan tingkat kepuasan pengguna. Artinya semakin tinggi motivasi pengguna untuk mengakses informasi dari aplikasi Petani, akan semakin tinggi pula kepuasan yang didapat oleh pengguna setelah menggunakan aplikasi Petani. Keduanya berkorelasi dengan $\mathrm{p}$ value 0.017 dan koefisien korelasi sebesar 0.431 , yang artinya keduanya memiliki hubungan yang positif dan signifikan.

\section{Hubungan Motivasi Integrasi dan Interaksi Sosial dengan Frekuensi Penggunaan Aplikasi Petani}

Selain kebutuhan untuk mengakses informasi, pengguna juga menggunakan aplikasi Petani untuk melakukan interaksi dengan pengguna lain. Interaksi antar pengguna dapat berupa bertanya dan memberikan jawaban tentang suatu masalah, mengetahui kondisi usaha pertanian pengguna lain, atau melakukan interaksi jual beli melalui berbagai layanan yang ada di aplikasi Petani. Perbedaan motivasi untuk berinteraksi antar pengguna menjadikan adanya perbedaan frekuensi pengguna dalam mengakses aplikasi Petani.

Mayoritas pengguna dengan tingkat motivasi sedang memiliki frekuensi penggunaan aplikasi Petani pada tingkat rendah, yaitu sebesar 85,7 persen, dan sisanya berada pada kategori frekuensi penggunaan pada tingkat sedang sebesar sebesar 9,6 persen dan tingkat tinggi sebesar 4,7 persen. Selebihnya pada tingkat motivasi tinggi, mayoritas pengguna berada pada tingkat frekuensi penggunaan yang rendah, yaitu sebesar 77,8 persen, dan sisanya berada pada tingkat frekuensi penggunaan yang sedang, yaitu sebesar 22,2 persen. Hal ini menunjukkan bahwa motivasi integrasi dan interaksi sosial yang dimiliki pengguna aplikasi Petani berhubungan dengan frekuensi penggunaan aplikasi Petani, tetapi hubungan yang ada tidak nyata dan tidak signifikan, karena dengan memiliki motivasi integrasi dan interaksi sosial yang tinggi belum tentu pengguna akan memiliki frekuensi penggunaan yang tinggi pula, begitu pun sebaliknya. Keduanya berkorelasi dengan $p$ value 0.173 dan koefisien korelasi sebesar 0.256 , yang artinya keduanya memiliki hubungan, namun korelasi di antara keduanya tidak nyata dan tidak signifikan.

\section{Hubungan Motivasi Integrasi dan Interaksi Sosial dengan Intensitas Penggunaan Aplikasi Petani}

Motivasi integrasi dan interaksi sosial yang dimiliki pengguna untuk mengakses aplikasi Petani juga berhubungan dengan berapa banyak waktu yang dialokasikan pengguna untuk 
mengakses aplikasi Petani. Perbedaan motivasi dari pengguna akan membuat pengguna mengalokasikan waktu yang berbeda pula saat mengakses aplikasi Petani.

Mayoritas pengguna dengan tingkat motivasi sedang memiliki intensitas penggunaan aplikasi Petani pada tingkat rendah, yaitu sebesar 90,4 persen, dan sisanya berada pada intensitas penggunaan yang sedang dan tinggi masingmasing sebesar sebesar 4,8 persen. Selebihnya, mayoritas pengguna dengan tingkat motivasi tinggi memiliki intensitas penggunaan pada tingkat rendah, yaitu sebesar 77,8 persen, dan sisanya berada pada intensitas penggunaan yang sedang, yaitu sebesar 22,2 persen. Hal ini menunjukkan bahwa motivasi integrasi dan interaksi sosial yang dimiliki pengguna aplikasi Petani berhubungan dengan intensitas penggunaan aplikasi Petani, tetapi hubungan yang ada tidak nyata dan tidak signifikan, karena dengan memiliki motivasi integrasi dan interaksi sosial yang tinggi belum tentu pengguna akan memiliki intensitas penggunaan yang tinggi pula, begitu pun sebaliknya. Keduanya berkorelasi dengan $p$ value 0.256 dan koefisien korelasi sebesar 0.214 , yang artinya keduanya memiliki hubungan, namun korelasi di antara keduanya tidak nyata dan tidak signifikan.

\section{Hubungan Motivasi Integrasi dan Interaksi Sosial dengan Tingkat Kepuasan Pengguna Aplikasi Petani}

Motivasi yang berbeda yang mendorong setiap orang dalam menggunakan media akan memberikan pengalaman yang berbeda pula kepada orang tersebut selama mengakses suatu media. Pengalaman yang berbeda inilah yang menghasilkan tingkat kepuasan yang berbeda pula untuk setiap individu yang mengakses media. Kepuasan akan diperoleh individu jika motivasinya dalam mengakses media telah terpenuhi.

Mayoritas pengguna dengan tingkat motivasi sedang memiliki tingkat kepuasan sedang, yaitu sebesar 81 persen, dan sisanya memiliki tingkat kepuasan tinggi sebesar 19 persen. Selebihnya, pada tingkat motivasi tinggi, mayoritas pengguna memiliki tingkat kepuasan tinggi, yaitu sebesar 77,8 persen, dan sisanya memiliki tingkat kepuasan sedang, yaitu sebesar 22,2 persen. Hal ini menunjukkan motivasi integrasi dan interaksi sosial memiliki hubungan dengan tingkat kepuasan pengguna. Artinya semakin tinggi motivasi pengguna, akan semakin tinggi pula kepuasan yang didapat oleh pengguna setelah menggunakan aplikasi Petani. Keduanya berkorelasi dengan $\mathrm{p}$ value 0.00 dan koefisien korelasi sebesar 0.636 , yang artinya keduanya memiliki hubungan yang positif dan sangat signifikan.

\section{Hubungan Frekuensi Penggunaan Aplikasi Petani dengan Tingkat Kepuasan Pengguna}

Penggunaan aplikasi Petani berkaitan dengan seberapa sering pengguna mengakses aplikasi Petani. Akses pengguna terhadap aplikasi tentu memberikan pengalaman yang berbeda-beda terhadap masing-masing pengguna. Pengalaman inilah yang akan menentukan apakah pengguna merasa puas dengan layanan aplikasi atau tidak.

Mayoritas pengguna dengan tingkat frekuensi penggunaan rendah memiliki tingkat kepuasan yang sedang, yaitu sebesar 64 persen, dan sisanya memiliki tingkat kepuasan yang tinggi, yaitu sebesar 36 persen. Pengguna dengan frekuensi penggunaan sedang memiliki tingkat kepuasan yang sedang dan tinggi, yaitu sebesar masing-masing 50 persen. Selebihnya, pengguna dengan frekuensi penggunaan yang tinggi memiliki tingkat kepuasan yang sedang. Hal ini menunjukkan bahwa frekuensi penggunaan aplikasi Petani berhubungan dengan tingkat kepuasan pengguna, tetapi hubungan yang ada tidak nyata dan tidak signifikan, karena dengan frekuensi penggunaan yang tinggi belum tentu pengguna akan memiliki tingkat kepuasan yang tinggi pula, begitu pun sebaliknya. Keduanya berkorelasi dengan $\mathrm{p}$ value 0.266 dan koefisien korelasi sebesar 0.210 , yang artinya keduanya memiliki hubungan, namun korelasi di antara keduanya tidak nyata dan tidak signifikan.

\section{Hubungan Intensitas Penggunaan Aplikasi Petani dengan Tingkat Kepuasan Pengguna}

Selain berkaitan dengan frekuensi, penggunaan aplikasi Petani juga berkaitan dengan berapa banyak waktu yang dialokasikan pengguna untuk mengakses aplikasi Petani. Perbedaan 
alokasi waktu pengguna inilah yang membuat pengguna memiliki pengalaman yang berbeda saat menggunakan aplikasi. Pengalaman yang berbeda ini mengakibatkan kepuasan yang dirasakan pengguna juga akan berbeda untuk masing-masing individu.

Mayoritas pengguna dengan intensitas penggunaan rendah memiliki tingkat kepuasan yang sedang, yaitu sebesar 65,4 persen, dan sisanya memiliki tingkat kepuasan yang tinggi, yaitu sebesar 34,6 persen. Pengguna dengan frekuensi penggunaan sedang memiliki tingkat kepuasan yang tinggi, yaitu sebesar 66,7 persen, dan sisanya memiliki tingkat kepuasan yang sedang, yaitu sebesar 33,3 persen. Selebihnya, pengguna dengan frekuensi penggunaan yang tinggi memiliki tingkat kepuasan yang sedang. Hal ini menunjukkan bahwa intensitas penggunaan aplikasi Petani berhubungan dengan tingkat kepuasan pengguna, tetapi hubungan yang ada tidak nyata dan tidak signifikan, karena dengan intensitas penggunaan yang tinggi belum tentu pengguna akan memiliki tingkat kepuasan yang tinggi pula, begitu pun sebaliknya. Keduanya berkorelasi dengan $p$ value 0.311 dan koefisien korelasi sebesar 0.192 , yang artinya keduanya memiliki hubungan, namun korelasi di antara keduanya tidak nyata dan tidak signifikan.

\section{SIMPULAN DAN SARAN}

\section{Simpulan}

Motivasi pengguna dalam menggunakan aplikasi Petani berkaitan dengan usaha pencarian informasi tentang pertanian dan sebagai media untuk belajar dari pengalaman pengguna lain serta untuk berinteraksi dan mengetahui keadaan usaha pertanian pengguna lain. Frekuensi dan intensitas penggunaan aplikasi Petani berada kategori rendah, karena pengguna hanya mengakses aplikasi Petani saat mereka membutuhkan suatu informasi tertentu atau ingin mendapatkan jawaban dari masalah pertanian mereka. Layanan aplikasi Petani yang paling banyak diakses oleh pengguna berdasarkan frekuensi dan intensitasnya adalah layanan Tanya Jawab, Artikel, dan Informasi Harga. Pengguna sudah cukup puas dengan layanan aplikasi Petani, yang artinya mereka puas dengan layanan yang ada namun masih memiliki beberapa saran untuk pengembangan aplikasi Petani ke depan.

Motivasi, penggunaan aplikasi Petani, dan tingkat kepuasan pengguna satu sama lain berhubungan. Hubungan di antara ketiga variabel tersebut memiliki kekuatan dan signifikansi yang berbeda-beda. Motivasi informasi memiliki hubungan yang positif dan signifikan dengan frekuensi dan intensitas penggunaan serta tingkat kepuasan pengguna. Motivasi integrasi dan interaksi sosial memiliki hubungan yang tidak nyata dan tidak signifikan dengan frekuensi dan intensitas penggunaan aplikasi Petani, namun memiliki hubungan yang positif dan sangat signifikan dengan tingkat kepuasan pengguna. Frekuensi dan intensitas penggunaan aplikasi Petani sama-sama memiliki hubungan yang tidak nyata dan tidak signifikan dengan tingkat kepuasan pengguna.

\section{Saran}

Penelitian selanjutnya disarankan untuk mengkaji lebih lanjut mengenai penggunaan aplikasi Petani dan bagaimana dampaknya terhadap kegiatan pertanian masyarakat, sehingga dapat diketahui sejauh mana petani mendapatkan manfaat dari aplikasi ini, tidak berhenti sampai tingkat kepuasannya saja.

Bagi pengembang aplikasi Petani, disarankan untuk menambah informasi mengenai pertanian organik, karena petani di lapang sangat mengharapkan adanya informasi yang lengkap mengenai hal-hal yang berkaitan dengan pertanian organik. Petani sudah berpikir untuk mengubah pola bertani mereka dan mengharapkan adanya informasi yang lengkap sebagai panduan. Selain itu, disarankan juga bagi pengembang untuk membuat feedback menjadi lebih cepat, agar waktu tunggu jawaban petani setelah bertanya menjadi lebih singkat dan informasi yang diperoleh dapat segera diterapkan.

Bagi pemerintah, disarankan untuk lebih mengedukasi masyarakat, khususnya petani, mengenai adanya teknologi informasi baru yang bermanfaat bagi petani melalui Dinas Pertanian maupun Petugas Penyuluh Lapang (PPL) setempat, karena informasi adanya aplikasi pertanian kurang diketahui oleh petani-petani di 
daerah akibat kurangnya sosialisasi kepada mereka.

\section{DAFTAR PUSTAKA}

[Agronomers] Aplikasi Andorid untuk petani [internet]. [diunduh pada 2017 Mar 5]. Tersedia pada http://www.agronomers.com/2016/06/7aplikasi-android-untuk-petani.html.

[BPPSDMP] Badan Penyuluhan dan Pengembangan SDM Pertanian. 2016. Informasi Database Penyuluh Pertanian [internet]. [diunduh pada 2016 Nov 17]. Tersedia pada

http://db.bppsdmp.pertanian.go.id/simluh/data penyuluh.

[Maxmanroe] Aplikasi Petani 8villages, saatnya petani menggunakan media sosial [internet]. [diunduh pada 2017 Mar 5]. Tersedia pada https://www.maxmanroe.com/aplikasi-petani8villages-saatnya-petani-indonesiamenggunakan-media-sosial.html

Kuntoro D. 2016. Aksesibilitas informasi dan kesenjangan pengetahuan petani kasus program Layanan Informasi Desa di Kabupaten Karawang Jawa Barat [tesis]. Bogor (ID): Institut Pertanian Bogor.

McQuail D. 1987. Teori Komunikasi Massa Edisi Kedua. Jakarta (ID): Erlangga.

Morrisan, Wardhani AC, Hamid UF. 2010. Teori Komunikasi Massa. Bogor (ID): Ghalia Indonesia.

Mulyandari RSH, Sumardjo, Lubis DP, Pandjaitan NK. 2010. Implementasi Cyber Extension dalam komunikasi inovasi pertanian. Jurnal Informatika Pertanian. Vol 19 (2): 17 - 43 [internet]. [diunduh pada 2016 Nov 2]. Tersedia pada http://www.litbang.pertanian.go.id/wartaip/pdf-file/2.retno_vol19-2-10.pdf.

Nurudin. 2007. Pengantar Komunikasi Massa. Depok (ID): PT. Rajagrafindo Persada.

Singarimbun M. 2014. Metode Penelitian. Dalam: Effendi $\mathrm{S}$ dan Tukiran, editor. Metode Penelitian Survei. Jakarta (ID): LP3ES. Hal 3 $-16$.

Sumardjo, Lubis DP, Mulyani ES, Mulyandari RSH. 2011. Manfaat sistem informasi berbasis teknologi informasi dan komunikasi untuk keberdayaan petani sayur. Jurnal Informatika Pertanian. Vol 20 (1): 1 - 13 [internet]. [diunduh pada 2016 Nov 2]. Tersedia pada https://www.google.co.id/url?sa=t\&rct=j\&q= \&esrc $=\mathrm{s} \&$ source $=$ web\&cd $=13 \&$ cad $=$ rja\&uact $=8 \&$ ved $=0$ ahUKEwjnms3ZwIrQAhWCq48K HX1YDs44ChAWCCcwAg\&url=http\%3A\%2 F\%2Fwww.litbang.pertanian.go.id\%2Fwartaip\%2Fpdf-

file\%2Fsumardjo_Vol20N01a.pdf\&usg=AFQj CNHuEQvqPe2CT8Ue-

XwmiSObR_U53A\&sig2=Z4V1_ANvUqCUO 83Jc4 oVA. 